\title{
Characterization of a D-lyxose isomerase from Bacillus velezensis and its application for the production of D-mannose and L-ribose
}

Zongren Guo ${ }^{1,2,3}$, Liangkun Long ${ }^{1,2,3}$ and Shaojun Ding ${ }^{1,2,3^{*}}$

\begin{abstract}
D-Mannose and L-ribose are two important monosaccharides, which have attracted public attention recently because of their great application potentials in food, cosmetic and pharmaceutical industries. Sugar isomerases catalyze the sugar isomerization and therefore can be used as the biocatalysts for production of the high-value sugars from inexpensive sugars. L-arabinose isomerase catalyzes the conversion of L-arabinose to L-ribulose, while D-lyxose isomerase catalyzes L-ribulose and D-fructose to L-ribose and D-mannose, respectively. In this paper, a putative D-LI from BacilI us velezensis (BvLI) was identified, characterized and used to produce D-mannose and L-ribose from D-fructose and L-arabinose, respectively. The recombinant BVLI exhibited a maximum activity at $55^{\circ} \mathrm{C}$ and $\mathrm{pH} 6.5$, in the presence of $0.1 \mathrm{mM} \mathrm{Co}^{2+}$. Approximately $110.75 \mathrm{~g} / \mathrm{L} \mathrm{D}$-mannose was obtained from $500 \mathrm{~g} / \mathrm{L} \mathrm{D}$-fructose in $6 \mathrm{~h}$ by the recombinant BVLI, and approximately $105 \mathrm{~g} / \mathrm{L}$ L-ribose was obtained from $500 \mathrm{~g} / \mathrm{L}$ L-arabinose in $8 \mathrm{~h}$ by the successive biocatalysis of L-arabinose isomerase from Bacillus licheniformis (BIAI) and BVLI.
\end{abstract}

Keywords: D-Mannose, L-Ribose, L-Arabinose isomerase, D-Lyxose isomerase, Bacillus velezensis

\section{Introduction}

$\mathrm{L}$-Ribose is the $\mathrm{C}$-2 epimer of $\mathrm{L}$-arabinose and the aldose isomer of L-ribulose. L-ribose can be used as initial material to synthesize various L-nucleoside derivatives as anticancer and antiviral drugs (Wang et al. 1998; Okano 2009; Xu et al. 2016). D-Mannose is the C-2 aldose isomer of $\mathrm{D}$-fructose and is a functional monosaccharide. It can promote the growth of intestinal probiotics and is used for the synthesis of the anti-tumor and immunostimulating drugs (Korneeva et al. 2012; Ranta et al. 2012; Zhang et al. 2017). Therefore, the synthesis of L-ribose and D-mannose was urgently demanded in industry (Beerens et al. 2012; Ban et al. 2017).

Many high-value monosaccharides were obtained from their isomeric forms by enzymatic reaction using sugar isomerases according to Izumoring strategy (Izumori 2006). Sugar isomerases possess diverse substrate

\footnotetext{
*Correspondence: dshaojun@hotmail.com; dshaojun@njfu.edu.cn ${ }^{1}$ The Co-Innovation Center of Efficient Processing and Utilization of Forest Resources, Nanjing Forestry University, Nanjing 210037, China Full list of author information is available at the end of the article
}

specificities; therefore can be applied to produce many high-value sugars from their abundant and inexpensive counterparts in nature (Patel et al. 2011; Beerens et al. 2012). D-Lyxose isomerase (D-LI, EC 5.3.1.15) is a crucial enzyme involves in microbial pentose metabolism (Cho et al. 2007; Kobayashi et al. 2018). It displayed extensive substrate specificity on aldose-ketose, and ability to catalyze the isomerization reaction between D-lyxose and D-xylulose, D-mannose and D-fructose, as well as L-ribose and L-ribulose, respectively. Recently, several D-lyxose isomerases have been identified and characterized (Anderson and Allison 1965; Cho et al. 2007; Kwon et al. 2010; Park et al. 2010a; Van et al. 2010; MarlesWright and Lewis 2011; Choi et al. 2012; Yu et al. 2016).

Due to the broad substrate specificity of D-LI, L-ribose and $\mathrm{D}$-mannose can be produced by the D-LI-catalyzed isomerization of L-ribulose and D-fructose, respectively. However, L-ribulose is an expensive and scarce sugar, so it is uneconomical to synthesize L-ribose from L-ribulose. Previous researches demonstrated that L-ribulose could be obtained from $\mathrm{L}$-arabinose by the isomerization catalysis of various L-arabinose isomerases (L-AI, EC 
5.3.1.4) from Bacillus licheniformis (Zhang et al. 2010), Bacillus coagulans (Zhou and Wu 2012) and Candida tropicalis (Yeo et al. 2018). Therefore, in an alternative way, L-ribose can be obtained from $\mathrm{L}$-arabinose, a cheap and widely available monosaccharide in lignocellulosic materials, via L-ribulose as an intermediate by a two-step isomerization using L-arabinose isomerase and D-lyxose isomerase.

In order to meet the demand for production of highvalue sugars in industry, sugar isomerases need to have good biochemical properties and thermal stability (De et al. 2017). The isomerization reaction catalyzed by sugar isomerases should be performed in slightly acidic to reduce unwanted by-products (Rhimi et al. 2009; Nguyen et al. 2018). But until now, few D-LIs can completely satisfy the industrial requirement. Therefore, novel D-LIs still need to be identified and characterized.

In this study, we identified a putative D-lyxose isomerase from B. velezensis CICC 24777. The putative D-LI from B. velezensis CICC 24777 was characterized and evaluated for its potential in the application for production of D-mannose and L-ribose.

\section{Materials and methods Materials}

All monosaccharides were purchased from Aladdin (Shanghai, China). FastPfu DNA polymerase and genomic DNA extraction kit were all procured from Transgene (Beijing, China). Restriction enzymes were all obtained from Takara (Japan). $2 \times$ Hieff Clone Enzyme Premix, Ni-NTA agarose gel column and sodium dodecyl sulfate-polyacrylamide gel electrophoresis (SDSPAGE) were obtained from Yeasen (Shanghai, China). The pET-21b $(+)$ expression vector was obtained from Miaoling (Hangzhou, China). And all other chemicals and reagents were analytical grade from Sinopharm group (Beijing, China).

\section{Bacterial strains and culture conditions}

Bacillus velezensis CICC 24777 strain was from this laboratory, and it was also deposited in China Center of Industrial Culture Collection (CICC). The host strains for gene cloning and expression were E. coli Top10 and E. coli BL21 (DE3) strains (Transgeen, Beijing, China), respectively. The $E$. coli cells were incubated in LuriaBertani (LB) medium in a shaker $\left(200 \mathrm{rpm}, 37^{\circ} \mathrm{C}\right)$.

\section{Cloning and expression of the BvLI}

According to the whole genomic sequence of $B$. velezensis DSM 7 (NCBI accession number: NC 014551.1), a putative D-lyxose isomerase gene sequence (WP 013351044.1) was identified. Based on the gene sequence, two oligonucleotide primes (the restriction enzyme sites were underlined) were designed to clone BvLI gene: BvLI-F:5'-TAAGAAGGAGATATACATATGACGATA TCGAAGCATGATGT-3' (NdeI); BvLI-R:5'-TCAGTG GTGGTGGTGGTGGTGCTCGAGAATGCGCGGGTC GGTGAAAA-3' (XhoI). Then the fragment encoding for the D-lyxose isomerase (BvLI) was amplified by PCR using the primers BvLI-F/BvLI-R and genomic DNA of $B$. velezensis CICC 24777 as template. The fragment was purified and inserted into pET-21b (+) digested with NdeI and XhoI by $2 \times$ Hieff Clone Enzyme Premix. The pET21b-BvLI was transformed into E. coli Top10 cells and BvLI gene was verified by sequencing. Then, the pET21b-BvLI was again transformed into E. coli BL21 (DE3) cells. The recombinant cells were cultured in LB medium including $100 \mu \mathrm{g} / \mathrm{mL}$ ampicillin at $37{ }^{\circ} \mathrm{C}$ until to the appropriate optical density $\left(\mathrm{OD}_{600}=0.5\right)$, then $0.5 \mathrm{mM}$ isopropyl- $\beta$-D-thiogalactopyranoside (IPTG) was added and cells were cultured at $25^{\circ} \mathrm{C}$ for $8 \mathrm{~h}$.

\section{Purification of recombinant BvLI}

The induced cells harboring pET21b-BvLI plasmid were collected by centrifugation $(8000 \times g, 20 \mathrm{~min})$. Then cell pellets were resuspended in lysis buffer $(50 \mathrm{mM}$ $\mathrm{NaH}_{2} \mathrm{PO}_{4}, 250 \mathrm{mM} \mathrm{NaCl}, \mathrm{pH}$ 8.0) and disrupted by sonication. Cell debris was precipitated after centrifugation $(12,000 \times g, 20 \mathrm{~min})$. The crude extract was loaded into a Ni-NTA agarose gel column previously equilibrated with the lysis buffer including $5 \mathrm{mM}$ imidazole, and the enzyme was purified according to the manufacturer's instructions. The purified enzyme solution was dialyzed against phosphate buffer $(50 \mathrm{mM}, \mathrm{pH} 8.0)$ at $4{ }^{\circ} \mathrm{C}$ for $24 \mathrm{~h}$. The protein concentration was assayed by BCA Protein Assay Kit (Sangon, Shanghai, China). The molecular mass of the recombinant enzyme was analyzed using $12 \%$ SDS-PAGE.

\section{Cloning, expression and purification of the recombinant BIAI}

According to the previously reported sequence encoding for the $\mathrm{L}$-arabinose isomerase (BlAI) from $B$. licheniformis (Prabhu et al. 2008), the gene (NCBI accession number: 3031327) was amplified from genomic DNA of $B$. licheniformis by using following primes (the restriction enzyme sites were underlined): BlAI-F:5'-TAAGAA GGAGATATACCATGGGCATGTTAACAACAGGGA AAAA-3' ${ }^{\prime}$ (NcoI); BlAI-R: $5^{\prime}$-TCAGTGGTGGTGGTG GTGGTGCTCGAGCTTAATCACTACATATTCCA-3' (XhoI). The amplified DNA fragment was inserted into pET-28a (+) digested with NcoI and XhoI. Then pET28aBlAI was transformed into E. coli BL21 (DE3) cells, the cells were incubated in LB medium including $100 \mu \mathrm{g} / \mathrm{mL}$ kanamycin and induced by IPTG for $8 \mathrm{~h}$ at $25^{\circ} \mathrm{C}$. The 
recombinant BlAI was purified and analyzed according to the above method.

\section{Enzyme assay}

The activity of the recombinant BvLI was assayed by determination of the amount of ketose obtained from the corresponding aldose. The reaction was proceeded in $50 \mathrm{mM}$ sodium phosphate buffer ( $\mathrm{pH}$ 6.5) including $10 \mathrm{mM} \mathrm{L}$-ribose, $0.1 \mathrm{mM} \mathrm{CoCl}_{2}$ and $0.5 \mathrm{U} / \mathrm{mL}$ of enzyme at $55{ }^{\circ} \mathrm{C}$ for $30 \mathrm{~min}$. Then the reaction was terminated by cooling samples on ice. The generated L-ribulose was measured by cysteine carbazole sulfuric acid method, and the absorbance was determined at $560 \mathrm{~nm}$ (Dische and Borenfreund 1951). One unit of the recombinant BvLI activity was defined as the amount of enzyme that formed $1 \mu \mathrm{mol} \mathrm{L}$-ribulose from L-ribose per min at $55^{\circ} \mathrm{C}$ and $\mathrm{pH}$ 6.5. The activity of the recombinant BlAI was determined according to the previous method described by Prabhu et al. (2008).

\section{Effects of temperature and $\mathrm{pH}$ on recombinant BvLI activity}

The influence of temperature on the recombinant BvLI activity was measured by varying temperatures from $30{ }^{\circ} \mathrm{C}$ to $65{ }^{\circ} \mathrm{C}$ in $\mathrm{pH} 6.5$. The influence of $\mathrm{pH}$ on the recombinant BvLI activity was measured at $55{ }^{\circ} \mathrm{C}$ with three different buffers, citrate buffer (50 mM pH 5.0-6.0), phosphate buffer (50 mM pH 6.0-8.0) and Tris- $\mathrm{HCl}$ buffer (8.0-9.0). The activity at each temperature or $\mathrm{pH}$ was relative to the maximum activity value $(100 \%)$.

Thermostability of the recombinant BvLI was investigated by assaying the residual enzyme activity after preincubating enzyme at a range of $45^{\circ} \mathrm{C}$ to $60^{\circ} \mathrm{C}$ for a specific time. The $\mathrm{pH}$ stability of the recombinant BvLI was evaluated by preincubating enzyme in $50 \mathrm{mM}$ phosphate buffer ( $\mathrm{pH}$ 5.0-9.0) for $24 \mathrm{~h}$. Then the enzyme activity was determined under standard reaction condition. The activity value of the recombinant BvLI without preincubation was determined as $100 \%$.

\section{Effect of metal ions on the activity of recombinant BvLI}

To determine the influence of metal ions on the recombinant BvLI activity, the recombinant BvLI was first dialyzed against $\mathrm{pH} 8.0$ including $10 \mathrm{mM}$ ethylene diamine tetraacetic acid (EDTA) at $4{ }^{\circ} \mathrm{C}$ for $12 \mathrm{~h}$, then enzyme was dialyzed against EDTA-free phosphate buffer $(\mathrm{pH}$ 8.0) at $4{ }^{\circ} \mathrm{C}$ for $12 \mathrm{~h}$. The activity of the recombinant BvLI was determined at $55{ }^{\circ} \mathrm{C}$ and $\mathrm{pH} 6.5$ containing several metal ions $\left(\mathrm{Cu}^{2+}, \mathrm{Zn}^{2+}, \mathrm{Fe}^{3+}, \mathrm{Mg}^{2+}, \mathrm{Ca}^{2+}, \mathrm{Co}^{2+}, \mathrm{Mn}^{2+}\right.$ and $\mathrm{Ni}^{2+}$ ) at a concentration of $1 \mathrm{mM}$. The influences of $\mathrm{Co}^{2+}$ and $\mathrm{Mn}^{2+}$ concentration on the recombinant BvLI activity were also measured by adding $\mathrm{Co}^{2+}$ or $\mathrm{Mn}^{2+}$ at concentrations from 0.1 to $1.5 \mathrm{mM}$. The activity of the recombinant BvLI without adding metal ion was used as a control (100\%).

\section{Determination of specific activity and kinetic parameters}

The specific activity of the recombinant BvLI was assayed under the standard conditions by using $10 \mathrm{mM}$ D-lyxose, D-mannose and L-ribose. Kinetic parameters of the recombinant BvLI were measured at $55^{\circ} \mathrm{C}$ and $\mathrm{pH} 6.5$ including $0.1 \mathrm{mM} \mathrm{CoCl}_{2}$ and 0 to $300 \mathrm{mM}$ substrate. The kinetic parameters Michaelis-Menten constant $\left(K_{\mathrm{m}}\right)$ and turnover number value $\left(K_{\text {cat }}\right)$ were measured by the Michaelis-Menten equation.

\section{Bioconversion of $\mathrm{D}$-fructose to $\mathrm{D}$-mannose by recombinant BvLI}

The effect of loading of the recombinant BvLI on the production of D-mannose was first studied. The loading of enzyme was varied from 5 to $30 \mathrm{U} / \mathrm{mL}$ for D-mannose production, and the reaction mixture $(100 \mathrm{~mL})$ was conducted in pH 6.5 including $500 \mathrm{~g} / \mathrm{L}$ D-fructose, $0.1 \mathrm{mM}$ $\mathrm{CoCl}_{2}$ and at $55{ }^{\circ} \mathrm{C}$ for $8 \mathrm{~h}$. Subsequently, the effect of substrate concentration on the conversion rate of D-mannose was also investigated. The reaction was performed in $\mathrm{pH} 6.5$ containing $25 \mathrm{U} / \mathrm{mL}$ enzyme and at $55^{\circ} \mathrm{C}$ for $8 \mathrm{~h}$, and the initial concentrations of $\mathrm{D}$-fructose were 100, 200, 300, 400 and $500 \mathrm{~g} / \mathrm{L}$, respectively. Finally, the D-mannose production was proceeded in $\mathrm{pH} 6.5$ including $500 \mathrm{~g} / \mathrm{L}$ D-fructose, $25 \mathrm{U} / \mathrm{mL}$ enzyme, and $0.1 \mathrm{mM}$ $\mathrm{CoCl}_{2}$ at $55^{\circ} \mathrm{C}$ for $8 \mathrm{~h}$.

\section{L-Ribose synthesis from L-arabinose by recombinant BIAI and BvLI}

Biotransformation of $\mathrm{L}$-arabinose to $\mathrm{L}$-ribose by using the recombinant BlAI and BvLI was proceeded in an orderly way. L-arabinose was first catalyzed by the recombinant BlAI (1 unit per gram of substrate) in $\mathrm{pH} 7.0$ including $500 \mathrm{~g} / \mathrm{L} \mathrm{L}$-arabinose, $0.1 \mathrm{mM} \mathrm{CoCl}{ }_{2}$ and $1.0 \mathrm{mM} \mathrm{MnCl}_{2}$ at $50{ }^{\circ} \mathrm{C}$ for $1 \mathrm{~h}$ (equilibrium phase), then the second reaction was performed at $55{ }^{\circ} \mathrm{C}$ by adding the different amount of recombinant BvLI (0.5-3.0 units per gram of substrate) for optimization of the enzyme loading. To investigate the effect of extra BvLI on the L-ribose conversion, additional $2.5 \mathrm{U} / \mathrm{g}$ L-arabinose of BvLI was supplemented at $2 \mathrm{~h}$ at the second reaction and the final concentration of L-ribose was compared with that of 2.5 $\mathrm{U} / \mathrm{g}$ L-arabinose of BvLI at $1 \mathrm{~h}$ only. Finally, the L-ribose conversion was systematically investigated at L-arabinose concentration ranged from 100 to $500 \mathrm{~g} / \mathrm{L}$ to biosynthesize L-ribose using $1 \mathrm{U} / \mathrm{g}$ L-arabinose of BlAI at the first reaction and $2.5 \mathrm{U} / \mathrm{g} \mathrm{L}$-arabinose of BvLI at the second reaction. 


\section{Analytical methods}

The concentrations of monosaccharide were detected by high-performance liquid chromatography (HPLC) system (Agilent 1200 series, USA) with a refractive index detector (Shimadzu) and a Sugar-pak1 column (6.5 $\mathrm{mm} \times 300 \mathrm{~mm}$, Waters). The column was eluted at $80{ }^{\circ} \mathrm{C}$ with deionized water at a flow rate of $0.4 \mathrm{~mL} / \mathrm{min}$ (Mei et al. 2016).

\section{Results}

\section{Cloning, expression and purification of recombinant BvLI and BIAI}

The putative BvLI gene (501 bp; GenBank accession number: MK836420) was successfully amplified from the genomic DNA of B. velezensis CICC 24777 and subcloned into pET-21b vector. The BvLI gene encodes 167 amino acids with theoretical molecular mass and isoelectric point values of 20042.28 $\mathrm{Da}$ and 5.11, respectively. The amino acid sequence of the putative BvLI exhibited high identity (77.84\%) with D-LI from B. licheniformis (Table 1). In addition, the phylogenetic tree further revealed a near relationship of the putative BvLI with D-LI from B. subtilis, D-LI from B. vallismortis and D-LI from B. licheniformis D-LI as well (Additional file 1: Fig. S1). Alignment of the amino acid sequence of BvLI with various characterized D-LIs confirmed that the metal coordination sites (H69, H71, E82 and H137) and substrate binding residues (K56, K80, E149 and D156) in BvLI were also conserved as all other D-LIs (Additional file 1: Fig. S2).

After recombinant $E$. coli BL21 (DE3) cells were induced with $0.5 \mathrm{mM}$ IPTG at $25^{\circ} \mathrm{C}$ for $8 \mathrm{~h}$, the target protein was purified via affinity chromatography with Ni-NTA agarose gel and subsequently analyzed by $12 \%$ SDS-PAGE. According to SDS-PAGE (Fig. 1), the supernatant contained a strong band of the target protein, while the cell debris contained little target protein. The molecular mass of purified target protein was

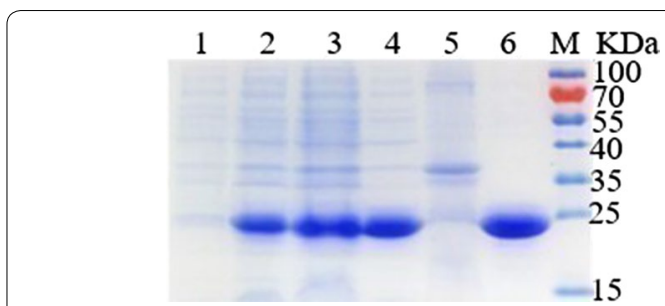

Fig. 1 SDS-PAGE analysis of purified recombinant BVLI. Lane 1-3: whole E. coli BL21 (DE3) cells without IPTG induction, after IPTG induction for $4 \mathrm{~h}$ and $8 \mathrm{~h}$, respectively; Lane 4, 5: supernatant and debris of induced cell lysate; Lane 6: purified recombinant BvLl; Lane M: protein marker

approximately $20 \mathrm{kDa}$, in accordance with the theoretical molecular weight. Which indicated that BvLI has been overexpressed as a soluble form protein in E. coli BL21 (DE3) cells.

The recombinant BlAI was also purified and analyzed according to the above method, the molecular mass of purified recombinant BlAI was approximately $53 \mathrm{kDa}$ (Additional file 1: Fig. S3), it was in line with the reported molecular weight of recombinant BlAI.

\section{The effects of temperature and $\mathrm{pH}$ on the activity of recombinant BvLI}

The influences of temperature on the recombinant BvLI activity and stability were determined and displayed in Fig. 2a, b. The optimal temperature of the recombinant BvLI was observed at $55{ }^{\circ} \mathrm{C}$, and the enzyme remained over $60 \%$ relative activity at $45{ }^{\circ} \mathrm{C}$ to $60{ }^{\circ} \mathrm{C}$. The enzyme activity decreased sharply when the temperature exceeded $60^{\circ} \mathrm{C}$, and only approximately $20 \%$ of initial activity was detected at $65^{\circ} \mathrm{C}$ (Fig. 2a). BvLI is stable at temperature below $50{ }^{\circ} \mathrm{C}$, and over $90 \%$ and $60 \%$ of the initial activities were remained after incubating the enzyme at $45^{\circ} \mathrm{C}$ and $50{ }^{\circ} \mathrm{C}$ for $10 \mathrm{~h}$, respectively. Approximately $21 \%$ of the initial activity were still retained after incubating the enzyme at $55^{\circ} \mathrm{C}$ for $10 \mathrm{~h}$ and the half-life

Table 1 Comparison of enzymatic character and amino acid sequences of $\mathrm{D}$-Lls from various microorganisms

\begin{tabular}{|c|c|c|c|c|c|}
\hline Origins & $\begin{array}{l}\text { Optimum } \\
\text { temperature }\left({ }^{\circ} \mathrm{C}\right)\end{array}$ & Optimum pH & $\begin{array}{l}\text { Optimum metal ion } \\
\text { and concentration }\end{array}$ & Identity (\%) ${ }^{a}$ & References \\
\hline Cohnella laevoribosii Rl-39 & 70 & 6.5 & $\mathrm{Mn}^{2+}, 1 \mathrm{mM}$ & 55.49 & Cho et al. (2007) \\
\hline Providencia stuartii KCTC 2568 & 45 & 7.5 & $\mathrm{Mn}^{2+}, 1 \mathrm{mM}$ & 48.63 & Kwon et al. (2010) \\
\hline Serratia proteamaculans KCTC 2936 & 40 & 7.5 & $\mathrm{Mn}^{2+}, 1 \mathrm{mM}$ & 17.11 & Park et al. (2010a) \\
\hline Escherichia coli 0157:H7 & 50 & 7.5 & $\mathrm{Mn}^{2+}, 1 \mathrm{mM}$ & 18.06 & Van et al. (2010) \\
\hline Bacillus licheniformis DSM 13 & $40-45$ & $7.5-8.0$ & $\mathrm{Mn}^{2+}, 1 \mathrm{mM}$ & 77.84 & Patel et al. (2011) \\
\hline Dictyoglomus turgidum DSM 6724 & 75 & 7.5 & $\mathrm{Co}^{2+}, 0.5 \mathrm{mM}$ & 55.80 & Choi et al. (2012) \\
\hline Thermosedimini-bacter oceani DSM 16646 & 65 & 6.5 & $\mathrm{Mn}^{2+}, 1 \mathrm{mM}$ & 61.88 & Yu et al. (2016) \\
\hline Bacillus velezensis CICC 24777 & 55 & 6.5 & $\mathrm{Co}^{2+}, 0.1 \mathrm{mM}$ & 100 & This study \\
\hline
\end{tabular}

a The identity of amino acid sequences between recombinant BVLI and other reported D-LIs 

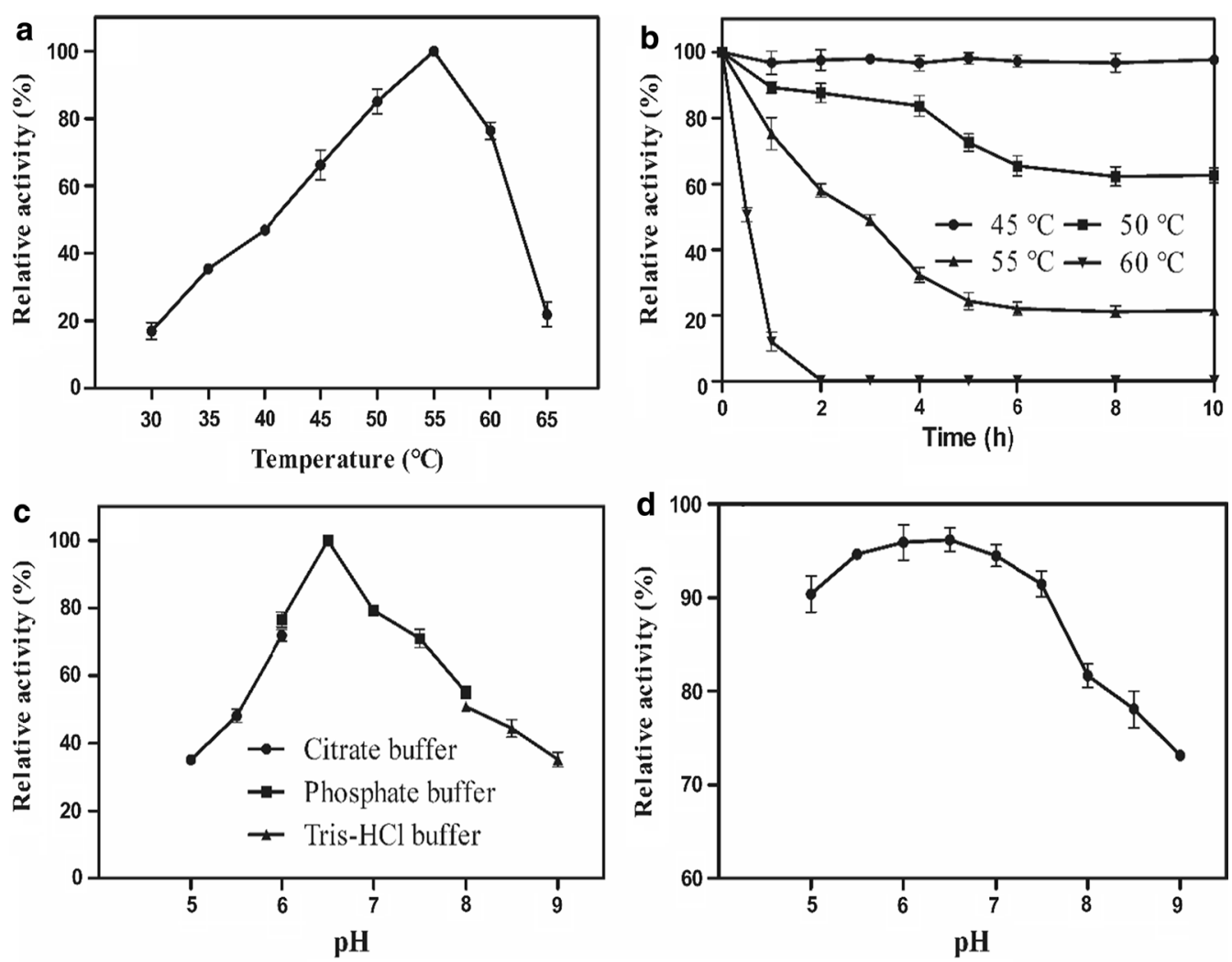

Fig. 2 The effects of temperature and $\mathrm{pH}$ on the activity and stability of recombinant BVLI. a The effect of temperature on the recombinant BVLI activity; $\mathbf{b}$ the effect of temperature on the thermostability of recombinant BVLI. c The effect of pH on the recombinant BVLI activity. $\mathbf{d}$ The effect of $\mathrm{pH}$ on the stability of recombinant BvLI. Data represented the mean \pm standard deviation from triplicate experiments

time is $3 \mathrm{~h}$ at $55^{\circ} \mathrm{C}$. The thermostability was decreased rapidly, and the half-life time was only about $0.5 \mathrm{~h}$ at $60{ }^{\circ} \mathrm{C}$ (Fig. 2b).

The recombinant BvLI displayed the highest activity at $\mathrm{pH} 6.5$ and retained over $70 \%$ of the initial activity at pH 6.0-7.5 (Fig. 2c). As shown in Fig. 2d, the enzyme remained over $90 \%$ of the initial activity at $\mathrm{pH} 5.0-7.5$ and over $70 \%$ of the initial activity at $\mathrm{pH} 7.5-9.0$ after incubating recombinant BvLI in $50 \mathrm{mM}$ phosphate buffer for $24 \mathrm{~h}$, respectively.

The effect of metal ions on the activity of recombinant BvLI The activity of the recombinant BvLI was detected at $55^{\circ} \mathrm{C}$ and $\mathrm{pH} 6.5$ containing various $1.0 \mathrm{mM}$ metal ions. As displayed in Fig. 3, $\mathrm{Co}^{2+}, \mathrm{Mn}^{2+}, \mathrm{Ni}^{2+}$ and $\mathrm{Mg}^{2+}$ significantly increased the enzyme activity approximately 4.1-, 3.6-, 3.0- and 1.6-fold, respectively. $\mathrm{Fe}^{3+}$ and $\mathrm{Ca}^{2+}$ have little effect on the enzyme activity, while $\mathrm{Cu}^{2+}$ and $\mathrm{Zn}^{2+}$ intensively inhibited the enzyme activity. The optimal concentrations of $\mathrm{Co}^{2+}$ and $\mathrm{Mn}^{2+}$ to stimulate the enzyme activity were 0.1 and $1.0 \mathrm{mM}$, respectively (Additional file 1: Fig. S4). Since $\mathrm{Co}^{2+}$ and $\mathrm{Mn}^{2+}$ can each stimulate the catalytic activity of recombinant BvLI,

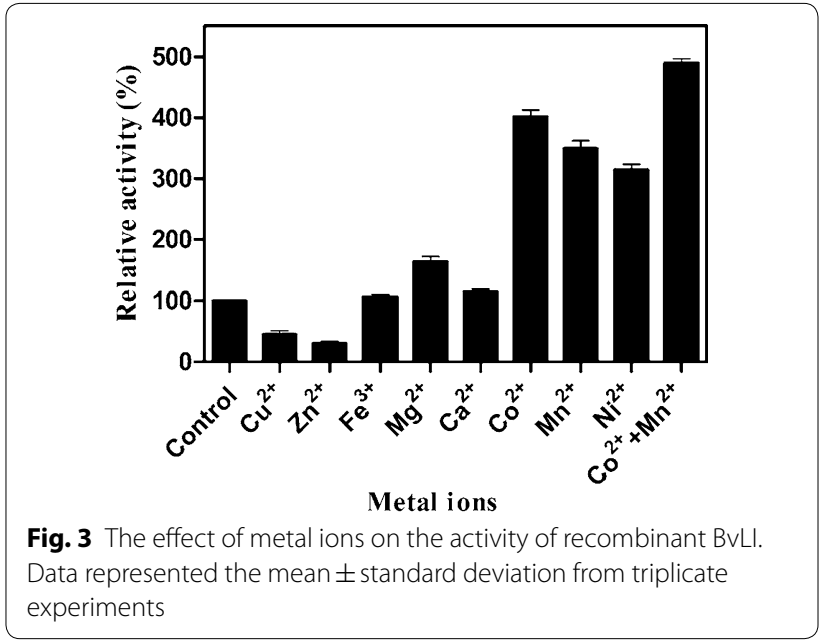

the combined effect of both metals on the activity of the recombinant BvLI was also assayed in this study. The enzyme activity was improved approximately 4.9-fold when simultaneously adding $0.1 \mathrm{mM} \mathrm{Co}^{2+}$ and $1.0 \mathrm{mM}$ $\mathrm{Mn}^{2+}$ (Fig. 3). 


\section{Specific activity and kinetic parameters of recombinant} BvLI

The specific activity and kinetic constant of the recombinant BvLI for D-lyxose, D-mannose and L-ribose were shown in Table 2 . The specific activity of the recombinant BvLI for D-lyxose was 3.38- and 4.40-fold higher than D-mannose and L-ribose, respectively. The $K_{\mathrm{m}}$ of the recombinant BvLI for D-lyxose was lower than D-mannose and L-ribose, which revealed that the recombinant BvLI exhibited the highest affinity toward D-lyxose. In addition, the $K_{\text {cat }}$ and $K_{\text {cat }} / K_{\mathrm{m}}$ of the recombinant BvLI for D-lyxose were also higher than D-mannose and L-ribose. These results demonstrated that D-lyxose was the most favorable substrate for the recombinant BvLI.

However, the ratio of $K_{\text {cat }} / K_{\mathrm{m}}$ value of D-mannose or L-ribose to D-lyxose, reflecting the relative specificity bias among three sugars, was different among D-LIs (Table 3). The ratio $K_{\text {cat }} / K_{\mathrm{m}}$ value of the recombinant BvLI for L-ribose to D-lyxose was 66.58-fold higher than D-LI from Cohnella laevoribosii RI-39, and the $K_{\text {cat }} / K_{\mathrm{m}}$ ratio of the recombinant BvLI for D-mannose to D-lyxose was higher among reported D-LIs, except of D-LI from Thermosediminibacter oceani DSM 16646 and E. coli $\mathrm{O} 157: \mathrm{H7}$. These results suggested that the recombinant BvLI has higher relative substrate specificity toward D-mannose and L-ribose compared with several reported D-LIs.

\section{D-Mannose production from D-fructose by recombinant BvLI}

The loading of recombinant BvLI for the D-mannose production from $500 \mathrm{~g} / \mathrm{L} \mathrm{D}$-fructose were varied from 5 to $30 \mathrm{U} / \mathrm{mL}$. As shown in Fig. 4a, the concentration of D-mannose increased with raising enzyme loading, and the D-mannose concentration reached a plateau at $25 \mathrm{U}$ enzyme $/ \mathrm{mL}$. When $\mathrm{D}$-mannose was produced from 100, 200, 300, 400 and $500 \mathrm{~g} / \mathrm{L}$ D-fructose by 25 $\mathrm{U} / \mathrm{mL}$ recombinant BvLI (Fig. $4 \mathrm{~b}$ ), the concentration of D-mannose increased with raising the concentration of $\mathrm{D}$-fructose, and the corresponding conversion rates were $23 \%, 22.85 \%, 22.64 \%, 22.45 \%$ and $22.15 \%$, respectively. As shown in Fig. 4c, when D-mannose production was proceeded in $500 \mathrm{~g} / \mathrm{L}$ D-fructose including $25 \mathrm{U} / \mathrm{mL}$ recombinant BvLI for $8 \mathrm{~h}$, the reaction reached equilibrium at $6 \mathrm{~h}$ and $110.75 \mathrm{~g} / \mathrm{L} \mathrm{D}$-mannose was obtained. The corresponding productivity of D-mannose was $18.46 \mathrm{~g} / \mathrm{L} / \mathrm{h}$. These results indicated that high levels of $\mathrm{D}$-mannose could be produced from $\mathrm{D}$-fructose by recombinant BvLI.

\section{L-Ribose synthesis from L-arabinose by recombinant BIAI and BvLI}

The recombinant BlAI displayed maximum activity at $\mathrm{pH} 7.5$ and $50{ }^{\circ} \mathrm{C}$ with $1.0 \mathrm{mM} \mathrm{Mn}{ }^{2+}$ addition, whereas the maximum activity of recombinant BvLI was observed at $55^{\circ} \mathrm{C}$ and $\mathrm{pH} 6.5$, in the presence of $0.1 \mathrm{mM}$

Table 2 Specific activity and Kinetic parameters of recombinant BvLI ${ }^{a}$

\begin{tabular}{|c|c|c|c|c|}
\hline Substrate & $\begin{array}{l}\text { Specific activity }(\mu \mathrm{mol} / \mathrm{min} / \\
\mathrm{mg})\end{array}$ & $K_{\mathrm{m}}(\mathrm{mM})$ & $K_{\text {cat }}\left(\min ^{-1}\right)$ & $K_{\text {cat }} / K_{\mathrm{m}}(\mathrm{min} / \mathrm{mM})$ \\
\hline D-Lyxose & $2.20 \pm 0.12$ & $33.14 \pm 2.53$ & $1335.89 \pm 22.54$ & $40.29 \pm 0.38$ \\
\hline D-Mannose & $0.65 \pm 0.04$ & $55.80 \pm 5.68$ & $1213.46 \pm 34.59$ & $21.78 \pm 0.91$ \\
\hline L-Ribose & $0.50 \pm 0.06$ & $151.4 \pm 16.33$ & $975.45 \pm 50.13$ & $6.44 \pm 0.11$ \\
\hline
\end{tabular}

${ }^{a}$ Values represented the mean \pm standard deviation from triplicate experiments

Table 3 The $K_{\text {cat }} / K_{\mathrm{m}}$ ratio of recombinant D-Lls for D-mannose or L-ribose to D-lyxose

\begin{tabular}{llll}
\hline Origins & $\left(\boldsymbol{K}_{\text {cat }} / \boldsymbol{K}_{\mathbf{m}}\right)_{\text {D-mannose }} /\left(\boldsymbol{K}_{\text {cat }} / \boldsymbol{K}_{\mathbf{m}}\right)_{\text {D-lyxose }}$ & $\left(\boldsymbol{K}_{\text {cat }} / \boldsymbol{K}_{\mathbf{m}}\right)_{\text {L-ribose }} /\left(\boldsymbol{K}_{\text {cat }} / \boldsymbol{K}_{\mathbf{m}}\right)_{\text {-lyxose }}$ & References \\
\hline C. laevoribosii RI-39 & 0.0165 & 0.0024 & Cho et al. (2007) \\
P. stuartii KCTC 2568 & 0.1734 & NR & Kwon et al. (2010) \\
S. proteamaculans KCTC 2936 & NR & Park et al. (2010a) \\
E. coli O157:H7 & 0.2152 & NR & Van et al. (2010) \\
B. licheniformis & 0.7529 & NR & Patel et al. (2011) \\
D. turgidum DSM 6724 & 0.5000 & NR & Choi et al. (2012) \\
T. oceani DSM 16646 & 0.1538 & NR & Yu et al. (2016) \\
B. velezensis CICC 24777 & 0.8607 & 0.1598 & This study \\
\hline
\end{tabular}

$\left(K_{\text {cat }} / K_{\mathrm{m}}\right)_{\mathrm{D}-\text { mannose }} K_{\text {cat }} / K_{\mathrm{m}}$ of recombinant D-Lls for D-mannose

$\left(K_{\text {cat }} / K_{\mathrm{m}}\right)_{\mathrm{L}-\text { ribose }} K_{\text {cat }} / K_{\mathrm{m}}$ of recombinant D-Lls for L-ribose

$\left(K_{\text {cat }} / K_{\mathrm{m}}\right)_{\mathrm{D}-\text { lyxose }} K_{\text {cat }} / K_{\mathrm{m}}$ of recombinant D-Lls for D-lyxose

$N R$ not reported 

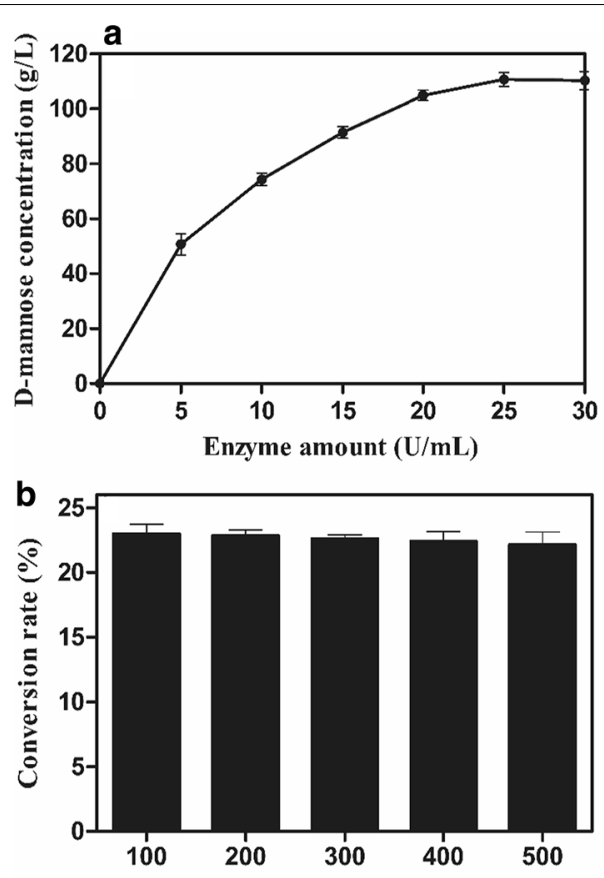

D-fructose concentration $(\mathrm{g} / \mathrm{L})$

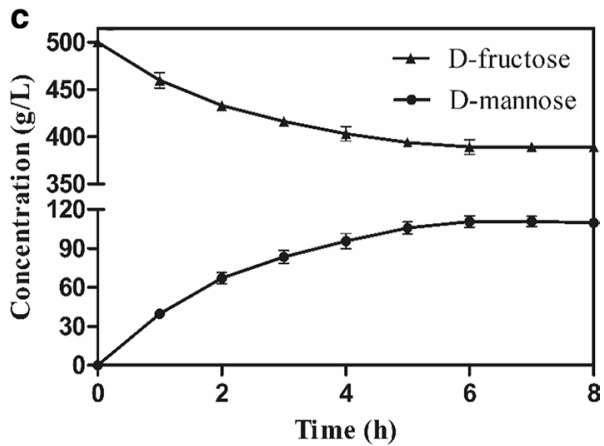

Fig. 4 D-Mannose production from D-fructose by recombinant BVLI. a Effect of loading of recombinant BVLI on the production of D-mannose. $\mathbf{b}$ Effect of substrate concentration on the conversion rate of D-mannose. c The production of D-mannose from $500 \mathrm{~g} / \mathrm{L}$ D-fructose by $25 \mathrm{U} / \mathrm{mL}$ recombinant BvLI. Data represented the mean \pm standard deviation from duplicate experiments

$\mathrm{Co}^{2+}$. Therefore, $\mathrm{L}$-ribose synthesis from $\mathrm{L}$-arabinose by applying the recombinant BlAI and BvLI was conducted in an orderly manner. As a result, the conversion rate of L-ribose reached a plateau when recombinant BvLI was $2.5 \mathrm{U} / \mathrm{g} \mathrm{L}$-arabinose (Fig. 5a). In addition, in order to know whether the adding extra BvLI has any effect on the conversion, additional $2.5 \mathrm{U} / \mathrm{g}$ L-arabinose of BvLI was added at $2 \mathrm{~h}$ in the second isomerization stage. It was observed the whole reaction reached faster equilibrium at $6 \mathrm{~h}$, but the final conversion rate of L-ribose and equilibrium ratio of L-arabinose, L-ribulose and
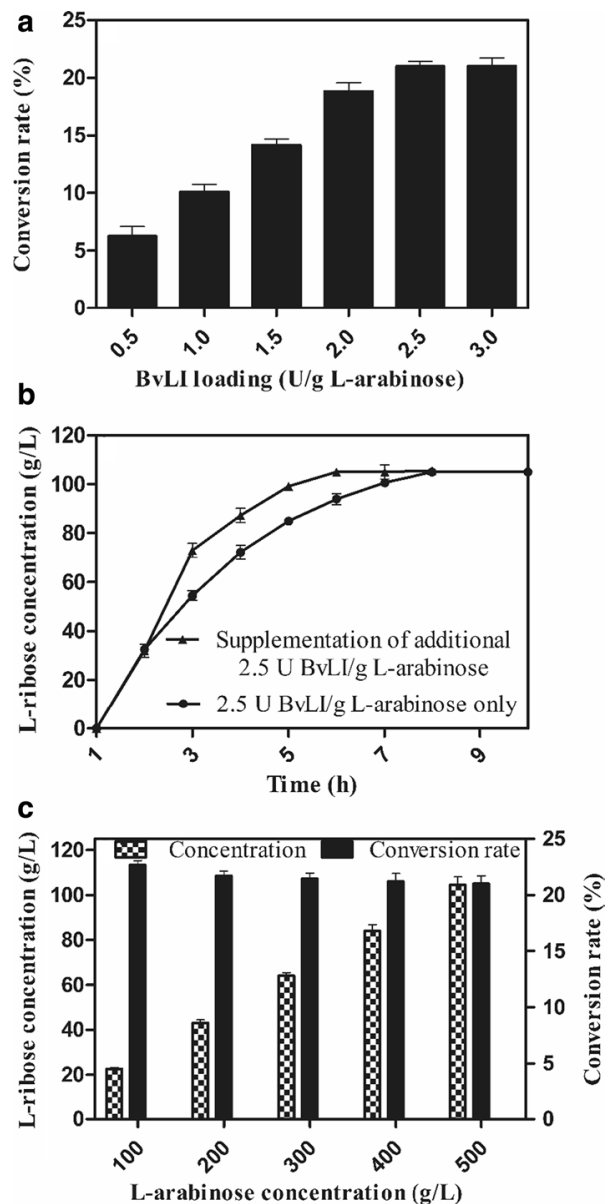

Fig. 5 Bioconversion of L-arabinose to L-ribose by the recombinant $\mathrm{BIAI}$ and $\mathrm{BVLI}$. a The conversion rate of L-ribose with different recombinant BVLI loading. $\mathbf{b}$ The effect of extra loading of BVLI on the production of L-ribose. $\mathbf{c}$ Bioconversion of L-ribose using different concentration of L-arabinose. Data represented the mean \pm standard deviation from duplicate experiments

L-ribose were not changed compared to that of $2.5 \mathrm{U} / \mathrm{g}$ L-arabinose of BvLI at $1 \mathrm{~h}$ only (Fig. 5b). Thus, $2.5 \mathrm{U}$ recombinant BvLI was added per gram of $\mathrm{L}$-arabinose in subsequent experiments. When the initial concentrations of L-arabinose were 100, 200, 300, 400 and $500 \mathrm{~g} / \mathrm{L}$, respectively, the increase of L-ribose concentration along with increasing $\mathrm{L}$-arabinose concentration. The corresponding conversion rates of L-ribose were $22.7 \%, 21.7 \% 21.4 \%, 21.2 \%$ and $21 \%$, respectively, indicating that a similar level of conversion rate could be retained at a high concentration of substrate. And $105 \mathrm{~g} / \mathrm{L}$ L-ribose were obtained from $500 \mathrm{~g} / \mathrm{L} \mathrm{L}$-arabinose and leaving $212.42 \mathrm{~g} / \mathrm{L}$ L-ribulose in $8 \mathrm{~h}$. The corresponding productivity of L-ribose was $13.12 \mathrm{~g} / \mathrm{L} / \mathrm{h}$ and the equilibrium ratio of L-arabinose, L-ribulose and L-ribose was approximately 1.74:2.02:1 (Fig. 5c). 


\section{Discussion}

In this study, a putative D-lyxose isomerase from $B$. velezensis was identified and overexpressed in $E$. coli BL21 (DE3) cells. Biochemical properties analysis has confirmed that the gene product BvLI displayed D-LI activity. The recombinant BvLI exhibited the maximum activity at slightly acidic condition ( $\mathrm{pH}$ 6.5) with good $\mathrm{pH}$ stability from $\mathrm{pH} 5.0-7.0$. In general, the production of high-quality sugars required a weakly acidic $\mathrm{pH}$ to reduce unwanted by-products in industry (Javad and Harry 1994; Xu et al. 2014). However, only D-LI from C. laevoribosii RI-39 and D-LI from T. oceani DSM 16646 showed the highest activity at pH 6.5 among the previously characterized D-LIs (Table 1). Therefore, from the view of $\mathrm{pH}$, the characteristics of BvLI such as a slightly acidic optimum $\mathrm{pH}$, and highly stable in weak acidity, was favorable for industrial application. Thermal stability is an important property for industrial applications of enzymes. It was reported that the half-life times of D-LIs from Serratia proteamaculans KCTC 2936 (Park et al. 2010a), Providencia stuartii KCTC 2568 (Kwon et al. 2010), and B. licheniformis DSM 13 (Patel et al. 2011) were 0.09, 1.4 and $7 \mathrm{~h}$ at $50{ }^{\circ} \mathrm{C}$, respectively. By comparison, the recombinant BvLI exhibited significantly higher thermostability at $50{ }^{\circ} \mathrm{C}$ than above three D-LIs. However, the half-life time of D-LI from Dictyoglomus turgidum DSM 6724 (Choi et al. 2012) was $9.1 \mathrm{~h}$ at $60{ }^{\circ} \mathrm{C}$, and the halflife time of D-LI from T. oceani DSM 16646 was $5.64 \mathrm{~h}$ at $70{ }^{\circ} \mathrm{C}$ (Yu et al. 2016), indicating that the thermostability of recombinant BvLI was relatively lower compared to above two D-LIs.

Metal ions play an important role in the catalytic reaction of D-LIs, and all the reported D-LIs have been identified to be metal-dependent enzymes (Table 1). In general, the optimum metal ions for $\mathrm{D}$-LIs activation was $\mathrm{Mn}^{2+}$, followed by $\mathrm{Co}^{2+}$ and $\mathrm{Ni}^{2+}$ at the optimal concentration of $1 \mathrm{mM}$. In this study, $\mathrm{Co}^{2+}$ and $\mathrm{Mn}^{2+}$ have a significant activation effect on the activity of D-LI, but unlike many previously reported D-LIs, the recombinant BvLI preferred $\mathrm{Co}^{2+}$ as a cofactor at an extreme low concentration requirement $(0.1 \mathrm{mM})$ to activate its catalytic activity. The maximum activation by $\mathrm{Co}^{2+}$ was also reported for D-LI from $D$. turgidum DSM 6724, however, a relatively higher concentration $(0.5 \mathrm{mM})$ of $\mathrm{Co}^{2+}$ was required. This observation suggested that different D-LIs from various sources may have different metal bias and binding affinity, although the amino acids responsible for metal binding are strictly conserved among all the reported D-LIs. Low concentration metal ion requirement is a favorable character for industrial application, hence, these results indicated that recombinant BvLI may be a potential candidate sugar isomerase for high-value sugars synthesis.
D-LIs efficiently catalyzed the reversible isomerization reaction between aldose and ketose sugars. So the isomerization capacity from aldose to ketose also reflects the capacity of the isomerization from ketose to aldose, although the substrate specificity for ketoses was higher than the corresponding aldoses for all characterized DLIs (Huang et al. 2018b). In this study, only aldose sugars including D-lyxose, D-mannose and L-ribose were used as substrates for biochemical property measurement, because their corresponding ketose products $\mathrm{D}$-xylulose, D-fructose and L-ribulose could be conveniently determined by cysteine carbazole sulfuric acid method. According to the crystal structure analysis (Protein Data Bank accession number: $3 \mathrm{KMH}$ ) and mutation results for crucial residues in active center of D-LI from $E$. coli O157:H7, the catalytic mechanism of D-LI was proposed to be a cis-enediolate-based mechanism (Van et al. 2010). D-LIs exhibited higher substrate specificity for some aldose such as D-lyxose and D-mannose, where in the C-2 and $\mathrm{C}-3$ hydroxyl groups were oriented to the left side and the $\mathrm{C}-4$ hydroxyl group was oriented to the right side, than L-ribose with the C-2, C-3 and C-4 hydroxyl groups oriented to the left side (Huang et al. 2018b). Similar as other D-LIs, BvLI exhibited the highest activity towards D-lyxose, followed by D-mannose and L-ribose. The $K_{\text {cat }}$ value for D-lyxose of recombinant BvLI is higher than $\mathrm{D}$ LI from E. coli O157:H7, but lower than other previously characterized D-LIs (Additional file 1: Table S1).

In this work, the potential to biosynthesize D-mannose from $\mathrm{D}$-fructose by recombinant BvLI was evaluated in different $\mathrm{D}$-fructose concentrations. It seemed that the conversion rate remained at a similar level irrespective of D-fructose concentrations at a fixed enzyme loading. Recently, several D-LIs have been identified and used to produce D-mannose. For example, the $10 \%$ (w/v) D-mannose was obtained from $50 \%(\mathrm{w} / \mathrm{v}) \mathrm{D}$-fructose in $5 \mathrm{~h}$ by D-LI from $S$. proteamaculans KCTC 2936, with a conversion rate of $20 \%$ (Park et al. 2010a). The free D-LI from $P$. stuartii KCTC 2568 produced 150 g/L D-mannose from $600 \mathrm{~g} / \mathrm{L} \mathrm{D}$-fructose in $2 \mathrm{~h}$, giving a conversion rate of $25 \%$ and a productivity of $75 \mathrm{~g} / \mathrm{L} / \mathrm{h}$ (Park et al. 2010b). D-LI from T. oceani DSM 16646 produced $101.6 \mathrm{~g} / \mathrm{L} \mathrm{D}-\mathrm{man}-$ nose from $400 \mathrm{~g} / \mathrm{L} \mathrm{D}$-fructose in $9 \mathrm{~h}$, giving a conversion rate of $25.4 \%$ and a productivity of $11.29 \mathrm{~g} / \mathrm{L} / \mathrm{h}$ (Yu et al. 2016). D-LI from Thermoflavimicrobium dichotomicum produced $110.5 \mathrm{~g} / \mathrm{L} \mathrm{D}$-mannose from $500 \mathrm{~g} / \mathrm{L} \mathrm{D}$-fructose with a conversion rate of $25.0 \%$ in $6 \mathrm{~h}$ (Zhang et al. 2018). By comparison, the conversion rate of $\mathrm{D}$-mannose by recombinant BvLI was higher than the previous reported D-LI from S. proteamaculans KCTC 2936, but slightly lower than the previous reported D-LI from $P$. stuartii KCTC 2568, T. dichotomicum and T. oceani DSM16646. It was wealth noted that the production of 
D-mannose from D-fructose by D-LI from P. stuartii was carried out in an alkaline condition ( $\mathrm{pH} 7.5)$. It was considered that alkaline condition might cause browning reactions (Chouayekh et al. 2007; Huang et al. 2018a), which was unfavorable for the production of D-mannose in industry. The recombinant BvLI displayed its maximum activity at a slightly acidic $\mathrm{pH}$ (pH6.5), which was similar to D-LI from T. oceani DSM 16646. Moreover, in this study, the productivity of D-mannose by using recombinant BvLI was 1.64-fold higher than D-LI from T. oceani DSM 16646 in the optimized condition. These results indicated that the recombinant BvLI possesses good potential to biosynthesize D-mannose from D-fructose.

In this study, the successive biocatalysis of L-arabinose isomerase (BlAI) and D-lyxose isomerase (BvLI) was employed for synthesis of L-ribose from L-arabinose. Increasing BvLI loading resulted in a higher conversion rate as expected, and the equilibrium reached at the loading of $2.5 \mathrm{U} / \mathrm{g} \mathrm{L}$-arabinose of BvLI (Fig. 5a). Supplementation of extra BvLI could improve the catalysis speed, but had not benefit for further increase of conversion rate, indicating that the isomerizations are equilibrium processes with thermodynamically limited yields of the products (Delidovich et al. 2017). Generally, for L-ribose synthesis from L-arabinose by a twostep isomerization reaction, the production of L-ribose from L-ribulose was a rate-limiting step in the whole reaction and final conversion rates mostly ranged from 15 to 25\% (Kim et al. 2014; Patel et al. 2017). For example, the production of L-ribose from $50 \mathrm{~g} / \mathrm{L}$ L-arabinose by using L-AI from Thermoanaerobacterium saccharolyticum NTOU1 and L-ribose isomerase from Geodermatophilus obscurus DSM 43160, giving a conversion rate of $15.9 \%$ in $12 \mathrm{~h}$, and the corresponding productivity of L-ribose was $0.66 \mathrm{~g} / \mathrm{L} / \mathrm{h}$ (Hung et al. 2015). When L-AI from shigella flexneri and D-LI from C. laevoribosii RI-39 were used as biocatalysts in an orderly manner, $2.53 \mathrm{mM}$ L-ribose was obtained from $10 \mathrm{mM} \mathrm{L}$-arabinose after $16 \mathrm{~h}$, giving a conversion rate of $25 \%$ and a productivity of $0.024 \mathrm{~g} / \mathrm{L} / \mathrm{h}$ (Patel et al. 2017). In this study, the conversion rate of L-ribose was higher than the study of Hung et al. while the productivity of L-ribose by using recombinant BlAI and BvLI was 19.88-fold and 546.67-fold higher than the study of Hung et al. and Patel et al., respectively. It was reported that xylulose conversion from xylose was significantly improved by removal of xylulose from the reaction mixture using simultaneous isomerization and reactive extraction ( $\mathrm{Li}$ et al. 2012). The conversion rate of L-ribose might be enhanced by removal of L-ribose to weaken end-product inhibition. Therefore, the separation of L-ribose and reuse of the remaining substrate were significant for industrial production of L-ribose and need to be further investigated in the future. However, it was worth noted that the separation of D-mannose or L-ribose from final reaction mixture was not easy It has been reported that L-ribose could be separated from L-arabinose by simulated movingbed chromatography (SMBC) (Juza et al. 2000; Song et al. 2019). Thus, SMBC would be a promising technique to separate high-value monosaccharides such as D-mannose and L-ribose from different isomers.

It was also reported that the conversion rate of L-ribose could reach over $70 \%$ by a single-step isomerization reaction using D-mannose-6-phosphate isomerase from Thermus thermophilus or L-ribose isomerase from Actinotalea fermentans ATCC 43279 and L-ribulose as substrate (Yeom et al. 2011; Tseng et al. 2017). However, it should be worth noted that L-ribulose was rare in nature and too expensive to produce L-ribose in industry. Therefore, L-arabinose should be considered as an ideal raw material for the synthesis of L-ribose, and further works still need to be carried out to improve the conversion rate of $\mathrm{L}$-ribose from L-arabinose.

In conclusion, a putative D-lyxose isomerase from B. velezensis CICC 24777 was cloned, expressed and characterized. The BvLI exhibited its maximum activity and excellent stability at a weakly acidic environment (pH6.5), and also exhibited a low concentration requirement of $\mathrm{Co}^{2+}$, indicating that BvLI is a novel DLI. The recombinant BvLI demonstrated good potential to synthesize D-mannose from D-fructose. It can also be used to synthesize L-ribose from L-arabinose with LAI by a two-step isomerization reaction. These results indicated that BvLI may be a good candidate isomerase for production of D-mannose and L-ribose.

\section{Supplementary information}

Supplementary information accompanies this paper at https://doi. org/10.1186/s13568-019-0877-3.

Additional file 1: Table S1. Comparsion of $K_{\text {cat }}$ of various D-LIs. Figure S1. The phylogenetic tree analysis of $\mathrm{D}$-lyxose isomerases of 19 amino acid sequences. (-) For this study. Numbers on nodes represent percentage bootstrap values for 1000 replicates. Figure. S2 Multiple alignment of the amino acid sequences of BVLI and other D-LIs from various microbiology. Figure. S3 SDS-PAGE analysis of purified recombinant BIAI. Lane M: protein marker; Lane 1, induced cell debris; Lane 2: crude extract of induced cell lysate; Lane 3: purified recombinant BIAI. Figure. S4 The effects of $\mathrm{Co}^{2+}$ and $\mathrm{Mn}^{2+}$ concentration on the activity of recombinant BVLI. Data represented the mean \pm standard deviation from triplicate experiments.

\section{Abbreviations}

D-LI: D-lyxose isomerase; L-Al: L-arabinose isomerase; BvLI: Bacillus velezensis D-lyxose isomerase; BIAI: Bacillus licheniformis L-arabinose isomerase; SDSPAGE: sodium dodecyl sulfate-polyacrylamide gel electrophoresis; IPTG: 
isopropyl- $\beta$-D-thiogalactopyranoside; LB: Luria-Bertani medium; HPLC: highperformance liquid chromatography.

\section{Acknowledgements}

Not applicable.

\section{Authors' contributions}

$Z G, L L$ and $S D$ designed the experiments, ZG executed the experiments. LL and SD analyzed experiments results. ZG and SD wrote and revised the manuscript. All authors read and approved the final manuscript.

\section{Funding}

This work was supported by the National Forestry Science and Technology Promotion Project [(2016)41], the Key Research and Development Program of Jiangsu (BE2015759).

\section{Availability of data and materials}

Not applicable.

\section{Ethics approval and consent to participate}

This article does not contain any studies with human participants or animals performed by any of the authors.

\section{Consent for publication}

Not applicable.

\section{Competing interests}

The authors declare that they have no competing interests.

\section{Author details}

${ }^{1}$ The Co-Innovation Center of Efficient Processing and Utilization of Forest Resources, Nanjing Forestry University, Nanjing 210037, China. ${ }^{2}$ Jiangsu Key Lab for the Chemistry \& Utilization of Agricultural and Forest Biomass, Nanjing Forestry University, Nanjing 210037, China. ${ }^{3}$ College of Chemical Engineering, Nanjing Forestry University, Nanjing 210037, China.

Received: 26 June 2019 Accepted: 9 September 2019

Published online: 16 September 2019

\section{References}

Anderson RL, Allison DP (1965) Purification and characterization of D-lyxose isomerase. J Biol Chem 240(6):2367-2372. http://www.jbc.org/conte nt/240/6/2367.citation

Ban J, Shabbir S, Lim M, Lee B, Rhee H (2017) Synthesis of L-ribose from D-ribose by a stereoconversion through sequential lactonization as the key transformation. Synthesis 49(18):4299-4302. https://doi. org/10.1055/s-0036-1588857

Beerens K, Desmet T, Soetaert W (2012) Enzymes for the biocatalytic production of rare sugars. J Ind Microbiol Biot 39(6):823-834. https://doi. org/10.1007/s10295-012-1089-x

Cho EA, Lee DW, Cha YH, Lee SJ, Jung HC, Pan JG, Pyun YR (2007) Characterization of a novel D-lyxose isomerase from Cohnella laevoribosii Rl-39 sp. nov. J Bacteriol 189(5):1655-1663. https://doi.org/10.1128/JB.01568-06

Choi JG, Hong SH, Kim YS, Kim KR, Oh DK (2012) Characterization of a recombinant thermostable D-lyxose isomerase from Dictyoglomus turgidum that produces D-lyxose from D-xylulose. Biotechnol Lett 34(6):1079-1085. https ://doi.org/10.1007/s10529-012-0874-y

Chouayekh H, Bejar W, Rhimi M, Jelleli K, Mseddi M, Bejar S (2007) Characterization of an L-arabinose isomerase from the Lactobacillus plantarum NC8 strain showing pronounced stability at acidic $\mathrm{pH}$. FEMS Microbiol Lett 277(2):260-267. https://doi.org/10.1111/j.1574-6968.2007.00961.x

De SM, Manzo RM, García JL, Mammarella EJ, Goncalves LRB, Pessela BC (2017) Engineering the L-arabinose isomerase from Enterococcus faecium for D-tagatose synthesis. Molecules 22(12):2164-2176. https://doi. org/10.3390/molecules22122164

Delidovich I, Gyngazova MS, Sanchez-Bastardo N, Wohland JP, Hoppe C, Drabo P (2017) Production of keto-pentoses via isomerization of aldo-pentoses catalyzed by phosphates and recovery of products by anionic extraction. Green Chem 20(3):724-734. https://doi.org/10.1039/C7GC03077K
Dische Z, Borenfreund E (1951) A new spectrophotometric method for the detection and determination of keto sugars and trioses. J Biol Chem 192(2):583-587. http://www.jbc.org/content/192/2/583.citation

Huang J, Yu L, Zhang W, Zhang T, Guang C, Mu W (2018a) Production of D-mannose from D-glucose by co-expression of D-glucose isomerase and D-lyxose isomerase in Escherichia coli. J Sci Food Agr 98(13):4895-4902. https://doi.org/10.1002/jsfa.9021

Huang J, Chen Z, Zhang W, Zhang T, Mu W (2018b) D-Lyxose isomerase and its application for functional sugar production. Appl Microbiol Biotechnol 102(5):2051-2062. https://doi.org/10.1007/s00253-018-8746-6

Hung XG, Yul MY, Chen YC, Fang TY (2015) Characterization of a recombinant L-ribose isomerase from Geodermatophilus obscurus DSM 43160 and application of this enzyme to the production of L-ribose from L-arabinose. J Mar Sci Technol 23(4):558-566

Izumori K (2006) Izumoring: a strategy for bioproduction of all hexoses. J Biotechnol 124(4):717-722. https://doi.org/10.1016/j.jbiotec.2006.04.016

Javad K, Harry EN (1994) The relationship between the coloured compounds present in the pressed liquor of cane sugar manufacture and those formed in Maillard reactions, in alkaline degradation of sugars, and in caramelisation. Food Chem 51(4):417-420. https://doi.org/10.1016/03088146(94)90195-3

Juza M, Mazzotti M, Morbidelli M (2000) Simulated moving-bed chromatography and its application to chirotechnology. Trends Biotechnol 18(3):108-118. https://doi.org/10.1016/S0167-7799(99)01419-5

Kim KR, Seo ES, Oh DK (2014) L-Ribose production from L-arabinose by immobilized recombinant Escherichia coli co-expressing the L-arabinose isomerase and mannose-6-phosphate isomerase genes from Geobacillus thermodenitrificans. Appl Biochem Biotechnol 172(1):275-288. https://doi. org/10.1007/s12010-013-0547-x

Kobayashi Y, Sahara T, Ohgiya S, Kamagata Y, Fujimori KE (2018) Systematic optimization of gene expression of pentose phosphate pathway enhances ethanol production from a glucose/xylose mixed medium in a recombinant Saccharomyces cerevisiae. AMB Express 8(1):139-149. https //doi.org/10.1186/s13568-018-0670-8

Korneeva OS, Cheremushkina IV, Glushchenko AS, Mikhailova NA, Baturo AP, Romanenko EE, Zlygostev SA (2012) Prebiotic properties of mannose and its effect on specific resistance. Zh Mikrobiol Epidemiol Immunobiol 5:67-70

Kwon HJ, Yeom SJ, Park CS, Oh DK (2010) Substrate specificity of a recombinant D-lyxose isomerase from Providencia stuartii for monosaccharides. J Biosci Bioeng 110(1):26-31. https://doi.org/10.1016/j.jbiosc.2009.12.011

Li B, Relue P, Varanasi S (2012) Simultaneous isomerization and reactive extraction of biomass sugars for high yield production of ketose sugars. Green Chem 14(9):2436-2444. https://doi.org/10.1039/C2GC35533G

Marles-Wright J, Lewis RJ (2011) The structure of a D-lyxose isomerase from the $\sigma^{B}$ regulon of Bacillus subtilis. Proteins 79(6):2015-2019. https://doi. org/10.1002/prot.23028

Mei W, Wang L, Zhang Y, Zhen Z, Ouyang J (2016) Characterization of an L-arabinose isomerase from Bacillus coagulans NL01 and its application for D-tagatose production. BMC Biotechnol 16:55-65. https://doi. org/10.1186/s12896-016-0286-5

Nguyen TK, Hong MG, Chang PS, Lee BH, Yoo SH (2018) Biochemical properties of L-arabinose isomerase from Clostridium hylemonae to produce D-tagatose as a functional sweetener. PLoS ONE 13:e0196099. https://doi. org/10.1371/journal.pone.0196099

Okano K (2009) Synthesis and pharmaceutical application of L-ribose. Tetrahedron Lett 65(10):1937-1949. https://doi.org/10.1016/j.tet.2008.11.047

Park CS, Yeom SJ, Lim YR, KimYS OhDK (2010a) Substrate specificity of a recombinant D-lyxose isomerase from Serratia proteamaculans that produces D-lyxose and D-mannose. Lett Appl Microbiol 51(3):343-350. https://doi. org/10.1111/j.1472-765X.2010.02903.X

Park CS, Kwon HJ, Yeom SJ, Oh DK (2010b) Mannose production from fructose by free and immobilized D-lyxose isomerases from Providencia stuartii. Biotechnol Lett 32(9):1305-1309. https://doi.org/10.1007/s1052 9-010-0300-2

Patel DH, Wi SG, Lee SG, Lee DS, SongYH Bae HJ (2011) Substrate specificity of the Bacillus licheniformis lyxose isomerase YdaE and its application in in vitro catalysis for bioproduction of lyxose and glucose by two-step isomerization. Appl Environ Microb 77:3343-3350. https://doi. org/10.1128/AEM.02693-10 
Patel MJ, Akhani RC, Patel AT, Dedania SR, Patel DH (2017) A single and two step isomerization process for D-tagatose and L-ribose bioproduction using L-arabinose isomerase and D-lyxose isomerase. Enzyme Microb Technol 97:27-33. https://doi.org/10.1016/j.enzmictec.2016.11.001

Prabhu P, Tiwari MK, Jeya M, Gunasekaran P, Kim IW, Lee JK (2008) Cloning and characterization of a novel L-arabinose isomerase from Bacillus licheniformis. Appl Microbiol Biotechnol 81(2):283-290. https://doi.org/10.1007/ s00253-008-1652-6

Ranta K, Nieminen K, Ekholm FS, Polakova M, Roslund MU, Saloranta T, Leino R, Savolainen J (2012) Evaluation of immunostimulatory activities of synthetic mannose-containing structures mimicking the $\beta$-(1,2)-linked cell wall mannans of Candida albicans. Clin Vac Immunol 19(11):1889-1893. https://doi.org/10.1128/CVI.00298-12

Rhimi M, Aghajari N, Juy M, Chouayekh H, Maguin E, Haser R, Bejar S (2009) Rational design of Bacillus stearothermophilus US100 L-arabinose isomerase: potential applications for D-tagatose production. Biochimie 91(5):650-653. https://doi.org/10.1016/j.biochi.2009.01.014

Song JR, Park H, Kim Jl, Mai NL, Koo YM (2019) Modified simulated moving bed chromatography with two pumps for sugar separation. Korean J Chem Eng 36(1):109-114. https://doi.org/10.1007/s11814-018-0175-9

Tseng WC, Wu TJ, Chang YJ, Cheng HW, Fang TY (2017) Overexpression and characterization of a recombinant L-ribose isomerase from Actinotalea fermentans ATCC 43279. J Biotechnol 259:168-174. https://doi. org/10.1016/j.jbiotec.2017.07.023

Van LS, Park CS, Yeom SJ, Adams-cioaba MA, Oh DK, Jia Z (2010) Structurebased annotation of a novel sugar isomerase from the pathogenic E. coli O157:H7. J Mol Biol 401(5):866-881. https://doi.org/10.1016/j. jmb.2010.06.063

Wang P, Hong JH, Cooperwood JS, Chu CK (1998) Recent advances in L-nucleosides: chemistry and biology. Anticancer Res 40(1-2):19-44. https://doi. org/10.1016/S0166-3542(98)00041-2

Xu Z, Li S, Feng X, Liang J, Xu H (2014) L-Arabinose isomerase and its use for biotechnological production of rare sugars. Appl Microbiol Biotechnol 98(21):8869-8878. https://doi.org/10.1007/s00253-014-6073-0

Xu Z, Sha Y, Liu C, Li S, Liang J, Zhou J, Xu H (2016) L-Ribose isomerase and mannose-6-phosphate isomerase: properties and applications for
L-ribose production. Appl Microbiol Biotechnol 100(21):9003-9011. https ://doi.org/10.1007/s00253-016-7834-8

Yeo IS, Shim WY, Kim JH (2018) Construction of genetically engineered Candida tropicalis for conversion of L-arabinose to L-ribulose. J Biotechnol 274:9-14. https://doi.org/10.1016/j.jbiotec.2018.01.019

Yeom SJ, Seo ES, Kim BN, Kim YS, Oh DK (2011) Characterization of a mannose-6-phosphate isomerase from Thermus thermophilus and increased L-ribose production by its R142N mutant. Appl Environ Microb 77(3):762-767. https://doi.org/10.1128/AEM.01793-10

Yu L, Zhang W, Zhang T, Jiang B, Mu W (2016) Efficient biotransformation of D-fructose to $D$-mannose by a thermostable $D$-lyxose isomerase from Thermosediminibacter oceani. Process Biochem 51(12):2026-2033. https://doi. org/10.1016/j.procbio.2016.08.023

Zhang YW, Jeya M, Lee JK (2010) L-Ribulose production by an Escherichia coli harboring L-arabinose isomerase from Bacillus licheniformis. Appl Microbiol Biotechnol 87(6):1993-1999. https://doi.org/10.1007/s0025 3-010-2600-9

Zhang D, Chia C, Jiao X, Jin W, Kasagi S, Wu R, Konkel JE, Nakatsukasa H, Zanvit P, Goldberg N, Chen Q, Sun L, Chen ZJ, Chen W (2017) D-Mannose induces regulatory $T$ cells and suppresses immunopathology. Nat Med 23(9):1036-1045. https://doi.org/10.1038/nm.4375

Zhang WL, Huang JW, Jia M, Guang C, Zhang T, Mu WM (2018) Characterization of a novel $\mathrm{D}$-lyxose isomerase from Thermoflavimicrobium dichotomicum and its application for D-mannose production. Process Biochem 83:131-136. https://doi.org/10.1016/j.procbio.2019.05.007

Zhou X, Wu J (2012) Heterologous expression and characterization of Bacillus coagulans L-arabinose isomerase. World J Microbiol Biotechnol 28(5):2205-2212. https://doi.org/10.1007/s11274-012-1026-1

\section{Publisher's Note}

Springer Nature remains neutral with regard to jurisdictional claims in published maps and institutional affiliations.

\section{Submit your manuscript to a SpringerOpen ${ }^{\odot}$ journal and benefit from:}

- Convenient online submission

- Rigorous peer review

- Open access: articles freely available online

- High visibility within the field

- Retaining the copyright to your article

Submit your next manuscript at $\boldsymbol{\Delta}$ springeropen.com 